\title{
Ultramontanismo, Maçonaria e Protestantismo no contexto da Questão Religiosa (1872-1875)
}

\author{
Ana Rosa Cloclet da Silva* \\ Thais da Rocha Carvalho**
}

\section{Resumo}

No Brasil, os acontecimentos associados à Questão Religiosa (1872-75) representaram etapa crucial na reconfiguração das relações entre o religioso e o secular. Desde então, a Igreja católica caminhou para a separação oficial e abrupta em relação ao Estado e para a conquista de sua identidade institucional, subordinada ao Sumo Pontífice. Na defesa deste projeto, clérigos e leigos ultramontanos fizeram da imprensa católica instrumento eficaz na nomeação de seus inimigos e preservação de sua influência junto à sociedade civil. É este o caso do jornal O Apóstolo - editado entre 1866 e 1901 e um dos mais expressivos da ortodoxia católica -, cuja análise pelo presente artigo visa reconstituir a construção discursiva de duas alteridades básicas do ultramontanismo: a maçonaria e o protestantismo. A partir da relação texto-contexto, identificou-se a base argumentativa que permitiu aos redatores do jornal anatemizar estes concorrentes no campo religioso cristão como "heréticos" e "anticlericais".

Palavras-chave: Ultramontanismo; Maçonaria; Protestantismo; Questão Religiosa; Imprensa Católica

* Docente da Faculdade de História da PUC-Campinas (desde 2008) e do Programa de Pós-Graduação Stricto Sensu em Ciências da Religião, pela mesma Universidade (desde 2012). É doutora em História pela Universidade Estadual de Campinas - UNICAMP (2000) e pós-doutora na mesma área pela Universidade de São Paulo - USP (2007). Email: anacloclet@gmail.com

** Mestre em Ciências da Religião pela Pontifícia Universidade Católica de Campinas, licenciada e bacharel em História e bacharel em Comunicação Social com habilitação em jornalismo, também pela Pontifícia Universidade Católica de Campinas. Email: thaiscarvalhosp@gmail.com 


\title{
Ultramontanism, Freemasonry and Protestantism in the context of the Religious Question (1872-1875)
}

\begin{abstract}
In Brazil, the events associated with the Religious Question (1872-75) represented a crucial stage in the reconfiguration of religious-secular relations. Since then, the Catholic Church has moved towards official and abrupt separation from the State and the conquest of its institutional identity, subordinated to the Supreme Pontiff. In defense of this project, clergymen and ultramontan laity made the Catholic press an effective tool in naming their enemies and preserving their influence with civil society. This is the case of the newspaper The Apostle - published between 1866 and 1901 and one of the most expressive of catholic orthodoxy -, whose analysis by this article aims to reconstitute the discursive construction of two basic alterities of ultramontanism: Freemasonry and Protestantism. From the relation text-context, it identified argumentative base that allowed the newspaper editors anathematize these competitors in the Christian religious field as "heretics" and "anticlerical".

Keywords: Ultramontanism; Freemasonry; Protestantism; Religious Question; Catholic Press

\section{Ultramontanismo, Masonería y Protestantismo en el contexto de la cuestión religiosa (1872-1875)}

\section{Resumen}

En Brasil, los acontecimientos asociados a la Cuestión Religiosa (1872-75) representaron etapa crucial en la reconfiguración de las relaciones entre lo religioso y lo secular. Desde entonces, la Iglesia católica caminó hacia la separación oficial y abrupta en relación al Estado y hacia la conquista de su identidad institucional, subordinada al Sumo Pontífice. En la defensa de este proyecto, clérigos y laicos ultramontanos hicieron de la prensa católica instrumento eficaz en el nombramiento de sus enemigos y preservación de su influencia junto a la sociedad civil. Este es el caso del periódico El Apóstol, editado entre 1866 y 1901 y uno de los más expresivos de la ortodoxia católica, cuyo análisis por el presente artículo pretende reconstituir la construcción discursiva de dos alteridades básicas del ultramontanismo: la masonería y el protestantismo. A partir de la relación texto-contexto, se identificó la base argumentativa que permitió a los redactores del periódico anatemizar a estos competidores en el campo religioso cristiano como "heréticos" y "anticlericales".

Palabras clave: Ultramontanismo; Masonería; Protestantismo; Cuestión Religiosa; Prensa católica 


\section{Introdução}

Nas últimas décadas, a revisitação dos fenômenos tradicionalmente associados ao advento das sociedades modernas e seculares tem estabelecido o relativo consenso teórico acerca da urgência de aproximações de caráter histórico, capazes de esclarecer a complexidade dos processos mediante os quais a religião surgiu de forma paralela e em relação dialética com o "secular" (ASAD, 2003), em cada situação específica.

Sob tal enfoque, rediscute-se a pertinência de uma moldura teórica formulada a partir da experiência das sociedades europeias ocidentais (HADDEN, 1987; CASANOVA 2006), indagando-se sobre outros processos históricos de construção da modernidade, onde a emergência de uma esfera pública secular não, necessariamente, implicou a perda das funções moralizadora e integradora da religião, com seu deslocamento para a esfera da autonomia individual.

Tais formulações inspiram revisitar o caso brasileiro onde, em virtude da longa vigência do padroado - o qual delineou um campo religioso dominado por uma religião oficial e institucionalmente fundida ao poder temporal - o processo de secularização - mesmo após a separação institucional entre Igreja católica e Estado, com a criação das condições jurídicas para a liberdade e o pluralismo religioso - preservou o catolicismo como "modelo e referência para a formulação de direitos e enquadramento das práticas populares enquanto práticas religiosas". (MONTERO, 2009, p. 10)

Neste caso, portanto, dizer que a secularização alude ao processo de ajuste da religião a fenômenos produzidos em planos que dela começavam a se diferenciar impõe adentrar a complexidade de um processo marcado pela atuação de diferentes atores e lógicas operativas, que fatalmente extrapola o âmbito estritamente institucional e normativo, explicando a capacidade do catolicismo de preservar sua influência junto à sociedade civil, bem como sua condição política inúmeras vezes privilegiada pelo próprio Estado (SILVA, 2017). De tal forma que, neste caso específico, as supostas condições da modernidade apresentaram uma inegável ligação com o religioso, da mesma forma que a instituição do modelo de Estado laico não foi acompanhada pela secularização da sociedade (ORO, 2011, p. 235).

Numa perspectiva histórica sobre o tema, é possível afirmar que, no Brasil, a segunda metade do século XIX representou uma etapa crucial na modelagem desta experiência singular de modernidade e secularização. Para além daquelas ideias e fenômenos mais diretamente associados ao "vendaval das liberdades modernas", que marcavam a conjuntura ocidental e começavam 
a "açoitar o Brasil" (CIARALLO, 2011, p. 93), tal conjuntura assistiu à radical reconfiguração do modelo de relacionamento entre Estado e Igreja, mediante a atuação combativa e propositiva assumida por clérigos e leigos ultramontanos ${ }^{1}$, defensores do primado pontifício sobre os assuntos de natureza religiosa e da autonomia institucional da Igreja católica em relação ao poder temporal.

Antenados com o que acontecia no mundo católico da época e orientados pelos documentos pontifícios emitidos desde o papado de Gregório XVI - com a Encíclica Mirari Vos, de 1832 -, seguido por Pio IX - que, em 1864, emitia a Encíclica Quanta Cura e seu anexo Syllabus - e pelo Concílio do Vaticano I (1870), aliaram-se corporativamente no combate ao liberalismo anticlerical, à maçonaria e ao pensamento filosófico científico contrários aos princípios da Igreja Romana. A tudo, enfim, que representasse os supostos "erros" da modernidade, ameaçadores do futuro da Igreja e da comunidade de fiéis.

Portanto, se desde a primeira metade do século o Brasil contou com a presença ultramontana no Parlamento e nas vias não institucionais - como a imprensa panfletária (SILVA; ROCHA, 2016) -, na conjuntura assinalada tiveram sua atuação reconfigurada nos marcos do movimento conhecido como a "romanização" da Igreja Católica: processo que tendeu a afirmar a autoridade de uma Igreja institucional e hierárquica, diretamente subordinada a Roma, ancorada no dogma da infalibilidade do poder papal e na defesa da sua identidade como instituição, levando seus representantes a se oporem ao “avanço da 'mentalidade do tempo', marcada pelo liberalismo, positivismo e pelo progresso da secularização” (SANTIROCCHI, 2015, 196).

Os rumos da reforma da Igreja e da específica via da secularização assumida no decorrer deste processo não podem ser dissociados dos acontecimentos delineados, sobretudo, na conjuntura de 1872-75. Foi neste contexto que a Igreja católica - cuja condição de religião oficial era garantida pelo Art. $5^{\circ}$. da Constituição de 1824 -, caminhou para a separação oficial e "abrupta" em relação ao Estado (RAMIRO JR., 2012, p. 8) - consolidada pela Constituição de 1891 - e para a conquista de sua identidade como instituição diretamente subordinada ao Sumo Pontífice.

Segundo Ítalo Domingos Santirocchi, "a palavra ultramontano deriva do latim, ultramontes, que significa "para além dos montes", isto é, dos Alpes." Sua origem, deriva da linguagem eclesiástica medieval que denominava todos os Papas não italianos. Acrescenta, ainda, que no século XVIII, o conceito passou a ser usado para "identificar os defensores da Igreja em qualquer conflito entre os poderes temporais e espirituais". (SANTIROCCHI, 2010. p. 24). 
Isto porque, se até 1872 o projeto de modernidade encampado pela vertente ultramontana e apoiado no "paradigma tridentino" (SANTIROCCHI, 2017) esteve relativamente afinado à autocompreensão "de que a Igreja Católica no Brasil estava visceralmente ligada à Sé Romana, mas que caminharia ao lado do trono" (PINHEIRO, 2009, p. 9), os acontecimentos iniciados naquele ano e que abririam um longo período de acirrados embates - opondo catolicismo ortodoxo e regalismo, papistas e conciliaristas, fundamento religioso e liberdades civis e políticas - levariam à cisão entre o Trono e o Altar.

Genericamente designados como a Questão Religiosa - ou, ainda, como $A$ Questão dos Bispos, on a Questão Maçônica (VILLAÇA, 1974, p.9) -, tais episódios inviabilizaram qualquer conciliação entre aquelas tendências articuladas aos diferentes modelos de secularização em voga: a tradição regalista, o "modelo intransigente romano" e a vertente que propugnava o modelo de Estado laico, defendendo a mais irrestrita "liberdade de consciência" conjugada a "paridade de oportunidades para todos os grupos" religiosos (DI STEFANO, 2008, p. 169). Deste então, a estratégia delineada pelos ultramontanos não se tratava mais "da participação de padres na política, mas de tentativa da hierarquia em definir uma política da Igreja perante o Estado”. (CARVALHO, 1981, p. 187).

À luz destas configurações históricas específicas, a partir das quais foram moldadas as condições da modernidade e da secularização no Brasil da segunda metade do século XIX, o presente artigo aborda aquela que se configurou numa das principais estratégias dos representantes do ultramontanismo, no sentido de designarem os supostos inimigos da Igreja e se manterem influentes junto à sociedade civil, à medida que diminuía sua influência política direta através do Estado e seus mecanismos institucionais: a atuação na imprensa periódica da época. Especificamente, analisa as performances discursivas veiculadas pelos ultramontanos - leigos e clérigos - no jornal O Apóstolo, editado entre os anos de 1866 e 1901, na província do Rio de Janeiro e um dos mais expressivos da ortodoxia católica da época ${ }^{2}$.

$\mathrm{Na}$ análise da fonte eleita, busca situar os dois sentidos de alteridade básicos construídos no plano discursivo pelos redatores doo jornal, os quais cumpriram o papel de "equivalente funcional da visibilidade" e da "legitimidade

2 Segundo Thiago Werneck Gonçalves (2012), que estudou os jornais maçônicos no período da Questão Religiosa, aponta $O$ Apóstolo como um jornal de significativa importância no estudo da Igreja Católica em relação ao conflito com a maçonaria, assim como com o Estado Imperial, pois foi um dos principais interlocutores dos periódicos maçônicos nesse período. (GONÇALVES, 2012). 
social" (MONTERO, 2012) por eles galgada: a maçonaria e o protestantismo. $\mathrm{Na}$ visão do Apóstolo, ambos apareciam associados à "hidra da fábula de diversas cabeças", representando "sempre o mesmo erro fatal com diversos nomes: na ordem pública - anarquia; na política - republicanismo; no domínio das ideias - filosofismo; na religião - protestantismo" (O Apóstolo, 7 de janeiro de 1866, ANO I, n. 1). Tendências estas que, no contexto analisado, foram genericamente englobadas pelos ultramontanos na condição de heréticas e anticlericais, conforme passaremos a analisar.

\section{A Questão Religiosa e a produção das alteridades anticatólicas}

A “Questão Religiosa”, como ficou conhecida, foi uma série de acontecimentos envolvendo a Igreja Católica, a maçonaria e o Governo Imperial, os quais repercutiram profundamente nas relações entre o Trono e o Altar. Iniciaram em virtude da condenação imposta ao padre José Luís de Almeida Martins pelo bispo do Rio de Janeiro, D. Pedro Maria de Lacerda, em represália ao fato daquele ter discursado na comemoração da Lei do Ventre Livre, organizada pela loja Maçônica Grande Oriente do Lavradio, em homenagem ao Visconde do Rio Branco - José Maria da Silva Paranhos - grão-mestre maçom e Presidente do Conselho de Ministros do Império ${ }^{3}$. Esta decisão foi apoiada pelos bispos do Pará - D. Antônio Macedo Costa - e o da diocese de Pernambuco - D. Vital - que em cumprimento às decisões pontifícias que condenavam a maçonaria, "requereram que as irmandades retirassem do seu grêmio os membros que pertenciam a dita sociedade secreta". O episódio levou as confrarias que se recusaram a cumprir tal determinação a apresentarem um "recurso à Coroa", que foi acatado, resultando ainda na condenação e prisão dos referidos bispos. (SANTIROCCHI, 2015).

Esses conflitos se estenderam até o ano de 1875 - quando os bispos ultramontanos foram anistiados - e reconfiguraram profundamente as relações entre Igreja, Estado e Maçonaria. Na verdade, a crise de 1872-1875 representou, segundo Ramiro Jr., "o estopim de um antagonismo permanente":

Primeiramente, já não era suportável o caráter conciliatório da Constituição de 1824. Em segundo lugar, fora um conflito social - maçonaria versus Igreja - com repercussão direta no gabinete imperial. Um dos espaços de discussão

3 O discurso do padre Almeida Martins - publicado no Jornal do Comércio, em 4 de março de 1872, segundo o jornal O Apóstolo. 
liberal no Brasil do século XIX eram as lojas maçônicas, enquanto o ecletismo religioso era presente, até mesmo parte do clero chegou a participar de levantes liberais e frequentar reuniões maçônicas. Contudo, a configuração da doutrina católica para o século XIX prometia uma ação em bloco na luta contra o liberalismo (...) Definitivamente, catolicismo e maçonaria não podiam andar juntos, papismo teocrático e legitimista era antitético às sociedades secretas promotoras de políticas liberais. (RAMIRO JR., 2012, p. 9-10).

A reação da maçonaria foi imediata ao afastamento do padre Almeida Martins. Críticas e ofensas ao bispo foram publicadas em todos os jornais maçons do período e, as duas Obediências Maçônicas uniram-se para combater todos os bispos ultramontanos, apesar de suas divergências ${ }^{4}$, fundindo-se no Grande Oriente Unido e Supremo Conselho do Brasil, de maio a setembro de 1872. Em 9 de maio, os maçons promoveram uma missa na Igreja do Bom Jesus, celebrada em desobediência às ordens de $\mathrm{D}$. Lacerda, mas que não teve punição como no caso de Almeida Martins (SANTIROCCHI, 2010a) ${ }^{5}$.

O apoio de D. Viçoso - bispo de Mariana - à D. Pedro Maria de Lacerda foi imediato, pedindo ao seu afilhado, Pe. Silvério Gomes Pimenta, que publicasse, em 27 de maio de 1872, seu folheto intitulado Juíro sobre a Maçonaria. Em carta, D. Viçoso, pediu para que Almeida Martins se retratasse e também escreveu diretamente a D. Pedro Maria de Lacerda, deixando claro sua posição a respeito do acontecido:

4 As duas Obediências tinham concepções diferentes. O Grande Oriente dos Beneditinos, tinha influência da maçonaria francesa, e combatia a ideia que a Maçonaria era, exclusivamente, filantrópica. Portanto, tinham uma atuação mais ativa em defesa dos princípios relacionados à modernidade como a liberdade de consciência, o racionalismo, o ensino laico e o casamento civil. Já o Grande Oriente do Lavradio, recebia influência da corrente inglesa. Sob o grão-mestrado do Visconde do Rio Branco, José Maria da Silva Paranhos, em dezembro de 1871, "foi publicado no Boletim do Grande Oriente do Brasil, uma resolução na qual se estabelecia o fechamento de todos os templos a maçons do Grande Oriente da França, ou daqueles que reconhecessem a supremacia deste (SANTIROCCHI, 2010a, p. 503).

5 Segundo Santirocchi, a essa vitória da maçonaria seguiu-se a publicação de um folheto intitulado "O ponto negro", que atacava a Santa Sé e o episcopado católico, em especial os bispos do Rio de Janeiro, do Pará, do Rio Grande do Sul, do Ceará e o recém-nomeado bispo de Pernambuco, D. Vital Maria Gonçalves de Oliveira. Na imprensa periódica o ataque foi também direcionado aos dogmas da Igreja, conforme os jornais "A Verdade", que negou a divindade de Cristo; "A Família Universal", negando a Santíssima Trindade; "O Pelicano", a Eucaristia; e em quatro edições, "A Verdade" escarneceu a virgindade de Maria" (SANTIROCCHI, 2010a, p. 510). Tal reação levou à publicação de listas de nomes de membros da maçonaria, em algumas localidades, como no caso de Pernambuco e do Pará. 
Muito de boa vontade, e me parece que em companhia de todo o Episcopado Brasileiro, aprovo e louvo o seu proceder no castigo desse infeliz Sacerdote. Ele se lembre que ninguém na hora da morte se fez maçom, antes muitos nessa hora das luzes tem abjurado a seita, reconhecendo o seu erro. A V. Exa. dou os parabéns, pois Deus o escolhe entre os Bispos do Brasil para ser o primeiro martirizado. Continue impávido. Deus é com sua respeitável Pessoa (S. G. PIMENTA, apud SANTIROCCHI, 2010a, p. 233).

Se olharmos o histórico de Padre Almeida Martins, pelo prisma ultramontano, podemos elencar os motivos pelos quais ele foi suspenso. Ele era membro da Grande Loja Vale dos Beneditinos, de tendência republicana e tinha relação com alguns anticlericais, entre eles o americano Carlos Jefferson Harrah, membro da Sociedade de Imigração Internacional e o padre convertido ao presbiterianismo, Francisco José de Lemos, que era também maçom (VIEIRA, 1980). Assim, maçonaria, republicanismo, anticlericalismo, imigração e protestantismo, eram associados e, no momento analisado, passaram a representar uma ameaça ao monopólio do capital religioso detido pela Igreja católica.

Vale ainda notar que, com exceção do tema da imigração, todas as demais supostas ameaças à Igreja estavam contempladas na lista de erros redigida por Pio IX - o Syllabus - e eram combatidos pelo Apóstolo desde sua criação, em 1866. Em 1874, este jornal declarou que Almeida Martins, ex-padre católico, era protestante (O APÓSTOLO, 10 de abril de 1874, Ano IX, n.42, p.4), essa declaração talvez venha da sua aproximação com Francisco José Lemos, em anos anteriores. Mas, também, em função da investidura dos presbiterianos que convidaram publicamente Almeida Martins a se converter ao protestantismo, o que não ocorreu (VIEIRA, 1980).

Em Pernambuco, o Bispo D. Vital Maria Gonçalves de Oliveira, após uma publicação do periódico $A$ Verdade - que listava o nome de maçons pertencentes a irmandades religiosas -, decretou a suspensão daqueles que não se desligassem da maçonaria. D. Vital interditou religiosamente algumas irmandades por não cumprirem a determinação do prelado de suspender os religiosos que se negassem a sair da maçonaria. Em 2 de fevereiro de 1873, publicou uma carta pastoral condenando as propagandas contra a Igreja e as irmandades advertidas, das quais apenas duas se submeteram às ordens do prelado, enquanto as demais foram sendo interditadas durante o período do conflito.

Como se pode notar, a Questão Religiosa envolveu embates muito mais complexos que aqueles observados entre maçonaria, Igreja e Estado. Con- 
forme analisado por Vieira, houve "de um lado, uma colisão do galicanismo, jansenismo, liberalismo, maçonaria, deísmo, racionalismo e protestantismo, todos vagamente 'aliados' contra o conservadorismo e ultramontanismo da Igreja Católica do Século XIX” (VIEIRA, 1980, p. 27).

Nas reflexões que seguem procuraremos analisar a repercussão dos episódios transcorridos entre 1872 e 1875 nas páginas do jornal O Apóstolo. Especificamente, interessa-nos averiguar como a "cooperação entre elementos liberais, maçônicos, republicanos, protestantes e de outros grupos minoritários, contra o poder político da Igreja Católica Romana no Brasil" (VIEIRA, 1980, p. 12) foi percebida e simbolicamente representada pelo discurso ultramontano, registrado pelo jornal.

\section{Maçonaria e anticlericalismo nas páginas do Apóstolo}

Desde a conquista de Roma, em 1870, os jornais católicos brasileiros atacavam a maçonaria em suas páginas, declarando-a anticristã e inteiramente responsável pela situação romana ${ }^{6}$. $\mathrm{Na}$ perspectiva da hierarquia católica ultramontana, ancorada nas diretrizes da Santa Sé, catolicismo e maçonaria não poderiam andar juntos. Contudo, como as Encíclicas e Bulas papais contra a maçonaria nem sempre recebiam o beneplácito do governo imperial brasileiro, existiam católicos maçons e era permitido o acesso de maçons a cargos políticos.

Neste sentido, é possível considerar pertinente para o caso brasileiro a mesma tendência observada para outros contextos latinoamericanos, nos quais a "dissidência anticatólica", assim como a maioria dos discursos anticlericais, durante o século XIX, eram "explicitamente religiosos", disputando com o catolicismo o mesmo capital simbólico". De tal forma que "a carga simbólica do sagrado, do transcendente, tem seu peso inclusive nas atitudes mais radicalmente 'antireligiosas"' (DI STEFANO, 2008, p. 158) 7.

É neste sentido que se deve compreender as disputas entre ultramontanismo e maçonaria, as quais configuravam um mesmo campo religioso cristão. Nas páginas do Apóstolo, a construção discursiva deste campo é marcada pelo significativo relevo conferido à maçonaria, que desde 1871 ganhava a atenção

\footnotetext{
6 Como exemplo da repercussão do tema nas páginas do Apóstolo, entre os anos de 1866 e 1870 o termo maçonaria, ou maçom aparece cerca de treze vezes em artigos do jornal. O ano de 1866 faz menção à maçonaria oito vezes, o que talvez isso se explique pela repercussão da publicação do Syllabus Errorium, que condenava as sociedades secretas. Tradução minha, do original em espanhol.
} 
do jornal, o qual publicou uma série de artigos combatendo as sociedades maçônicas, num momento em que a Questão Religiosa ainda não tinha germinado seus frutos mais significativos.

No ano seguinte, $O$ Apóstolo passou por uma mudança editorial: apesar de manter o número de páginas, aumentou o número de colunas, passando de três para cinco. Naquele mesmo ano, o conflito com a maçonaria se intensifica e, a respeito dos acontecimentos iniciados com a publicação do discurso de Almeida Martins no Jornal do Comércio, O Apóstolo respondeu em sua edição de $n^{\circ} .10$, datada de 10 de março, atacando o Visconde do Rio Branco e a maçonaria. Particularmente, condenava a doutrina citada pelo referido discurso, que pregava ser o homem dotado de uma "partícula da Divindade", sendo assim a própria essência de Deus em parte, não sendo criado à sua imagem e semelhança. $\mathrm{Na}$ visão do Apóstolo, essa teoria seria "panteísta" e, portanto, condenada pelo Concílio do Vaticano, conflitando com os dogmas católicos:

Só a Maçonaria, e pela voz do seu grão-mestre, poderá sustentá-la, como sustenta o deísmo puro, admitindo para seu grêmio ainda aqueles que só reconhecem a existência de Deus. É isto resultado imediato da liberdade religiosa que professa e propaga (O Apóstolo, 10 de março de 1872, ANO VII, n. 10).

Observa-se aqui um dos elementos cardinais que norteava a crítica ultramontana à maçonaria, associando-a ao anticlericalismo do século. Especificamente, trata-se do seu caráter "intelectivo", onde o deísmo - assim como o panteísmo - eram condenados como "falsa crença", implicando a exteriorização de uma opinião errônea acerca de algum artigo da fé cristã (CAVALLERO, 2012). No caso assinalado, condenava-se a concepção deísta, segundo a qual Deus era concebido como um ser que apenas dera início ao movimento do Universo; para outras concepções dessa mesma corrente, a religião deveria se limitar à razão ou apenas ser uma religião moral, no sentido kantiano, que valorizasse o plano terrestre, material.

Vale ainda lembrar que, tanto o panteísmo, quanto o naturalismo e o racionalismo absoluto, converteram-se nos primeiros erros elencados pelos Syllabus, editado por Pio IX em dezembro de 1864, dos quais a Igreja derivou sete proposições falsas, sendo uma delas a que afirmava que o homem e o mundo teriam a mesma substância que Deus ${ }^{8}$. Essa teoria, segundo o jornal,

8 No Syllabus essa afirmação aparece da seguinte maneira: "Não existe Divindade alguma suprema e sapientíssima e providentíssima, distinta desta universalidade das coisas, e Deus 
só poderia ser sustentada pelos maçons, pois a Igreja não a reconhecia como verdadeira, sendo um erro oriundo da "liberdade religiosa", entendida, nesse trecho, como derivação da liberdade de consciência.

Daí, portanto, que ao caráter intelectivo do que era reconhecido como verdadeira heresia pelo jornal O Apóstolo, somava-se o "elemento volitivo": a sustentação pertinaz e pública de uma opinião errônea (pertinax defensio). Neste caso, a exteriorização da opinião "herética" se dava por meio daquele que, conforme reconhecido pelos redatores do Apóstolo, representava um dos principais instrumentos do século, mobilizado pelos inimigos da Igreja: a "imprensa ímpia”, expressão que designava os jornais leigos que não professavam a mesma causa, assim como a imprensa protestante, cuja difusão no Brasil se dá a partir da década $1860^{\circ}$.

$\mathrm{Na}$ sua edição $\mathrm{n}^{\circ}$. 29, de 22 de julho de 1866, o jornal informava sobre o breve ao Civiltá Cattolica, enviado pelo Papa Pio IX, expressando esta concepção acerca do significado paradoxal assumido pela imprensa, reconhecida como principal instrumento mobilizado pelos inimigos do catolicismo, embora indispensável na modelagem da realidade material e simbólica segundo os desígnios ultramontanos. Segundo o jornal:

Ninguém pode pois desconhecer que a imprensa periódica e não periódica é nas mão dos inimigos da Igreja, a arma mais mortífera para combater qualquer espécie de bem e seduzir os espírito mais retos e sinceros. Para remediar a tão grande mal era necessário que homens cheios de coragem e talento, que padres zelosos, principalmente, empreendessem a obra mais salutar que é preciso tentar - a de oporem-se aos ataques tão perigosos da imprensa ímpia com as armas ministradas pela imprensa católica ( $O$ Apóstolo, 22 de julho de 1866, ANO I, n. 29).

Por isso o ataque veemente do Apóstolo à publicação do discurso do padre Almeida Martins pelo Jornal do Comércio, ao qual advertia com as seguintes palavras:

é o mesmo que a natureza das coisas, sujeito, portanto, a mudanças, e Deus, na realidade, se forma no homem e no mundo, e todas as coisas são Deus e tem a mesma substância de Deus; Deus é uma e a mesma coisa que o mundo, e, portanto, o espirito é o mesmo que a matéria, a necessidade que a liberdade, a verdade que a falsidade o bem que o mal, e a justiça que a injustiça" (SYLLABUS, 1864).

9 Destaca-se nas páginas do Apóstolo o embate direto com o principal periódico protestante da época: a Imprensa Evangélica, que começou a circular no ano de 1864. 
Que um leigo, ignorante da gravidade das penas eclesiásticas, se filie em sociedades condenadas, e viva sob a pressão dessas penas, podem haver razões que atenuem seu mau procedimento; [mas] nunca porém haverá atenuante para Padre, que não pode ignorá-las e que sabe quanto elas afetam imediatamente o seu sagrado ministério (O Apóstolo, 10 de março de 1872, ANO VII, n. 10).

Ainda neste trecho, o jornal expunha o terceiro elemento norteador da construção semântica do que passava a ser visto como "heresia" e "anticlericalismo". Trata-se da crítica amparada pela ideia da separação (divisio) em relação à verdadeira doutrina e à Igreja institucionalizada: a primeira, representada pelo catolicismo e justificada pela revelação (veritas); a segunda, sustentada pela hierarquia da Igreja católica, possuidora da verdade e guardiã da tradição (eclesia) (CAVALLERO, 2012). Assim, prosseguia:

Desobediência e blasfêmia ao mesmo tempo!!! Sirva porém o triste espetáculo que deu para princípio de sua conversão, lembrando-se da ofensa que lançou à corporação a que pertence, e sobretudo da injúria que fez, (acreditamos que irrefletidamente) ao próprio Jesus-Cristo, que para guarda da doutrina da Redenção da humanidade só constituiu a Igreja Católica, Apostólica Romana, a quem deu poderes extraordinários e disse: Qui vos audit, me audit; qui vos spernit, me spernit10. (O Apóstolo, 10 de março de 1872, ANO VII, n. 10).

Sobre tais "poderes extraordinários", instituídos e santificados por Deus, assentava-se a autocompreensão da Igreja como instituição legítima e superior a qualquer outra na terra. Assim, no caso de um "leigo, ignorante" de tal gravidade, o erro era atenuado; mas um padre, que pelo sacerdócio havia sido santificado e estudado os dogmas eclesiásticos, ofendia-se o próprio Jesus Cristo, por compactuar com uma sociedade perigosa e condenada pela Igreja. Em outros artigos desse mesmo ano, encontram-se diversos argumentos supostamente atestadores da periculosidade da maçonaria para a sociedade. Em artigo que traz notas do Monsenhor de Ségur ${ }^{11}$, os ideais maçônicos -

10 "Quem vós escuta, me escuta; quem vós rejeita, me rejeita". (tradução nossa).

11 Louis Gaston de Ségur nasceu em Paris a 15 de abril de 1820. Descendente de uma família nobre, formou-se em Direito e foi imediatamente enviado como adido à Embaixada Francesa em Roma, junto à Santa Sé, para o sacerdócio. Ao retornar a Paris, ingressou no Seminário de Santo Sulpício, sendo ordenado sacerdote em dezembro de 1847. Dedicou-se à evangelização de crianças, pobres e soldados prisioneiros de guerra. Mas devido a um problema na visão que o levaria à cegueira, passou a ditar livros explicando - e defendendo com fervor - a doutrina católica em linguagem popular. Até o momento de sua morte, em 1881, seus livros somavam 700 mil cópias vendidas apenas na França e na Bélgica, sem contar as edições em italiano, espanhol, alemão, inglês e até mesmo na língua hindu. (Disponível em: <https://ecclesiae.com.br/index.php?route=product/ author\&author_id=87>. Acesso em: 22 de outubro de 2018). 
como a felicidade, a igualdade social e a liberdade - eram apontados como a arma mediante a qual seus representantes iludiam os desgostosos com a religião católica, como lobos que se apoderavam de cordeiros. Assim, em função desta influência, argumentava em edição de 30 de junho de 1872:

A desorganização social reina por toda a parte; está no norte e no meio dia. Tudo tem experimentado o nível ao qual queremos abaixar a espécie humana. Tem por certo havido grande facilidade em perverter. Por toda a parte achei na Europa os espíritos muito inclinados para a exaltação: toda a gente confessa que o velho mundo está a desabar e que os reis têm completado o seu tempo (O Apóstolo, 30 de junho de 1872, ANO VII, n. 26).

$\mathrm{Na}$ interpretação do jornal, estes princípios plantados pela "França revolucionária" - que "foi e é desgraçadamente a escola dos nossos políticos, antes e depois da independência" ( $O$ Apóstolo, n. 29, 1870) -, eram abraçados e difundidos pela maçonaria, inimigo o mais execrável da sociedade brasileira, pois: "disfarçando-se debaixo de certas aparências de piedade (...) trabalha ao mesmo tempo [para] solapar com mão sacrílega e misteriosa os alicerces da autoridade eclesiástica" (O Apóstolo, n. 10, 1873). Nas páginas do jornal, a maçonaria era vista mesmo como a própria "Revolução em ação", movendo tanto a revolução de 1789, como os princípios socialistas em voga no mundo ocidental, a partir de meados do século XIX. Conforme publicado na edição de 13 de julho de 1873:

A maçonaria não tem feito só revoluções, ela é a Revolução mesma. Ela é a desorganização social reduzida a sistema; é o socialismo! É a negação da autoridade" (...) O que foi a grande Revolução, a Revolução por excelência, começada em 1789, senão a maçonaria em ação? (...) É impossível negar que a soberania do homem, a liberdade e a fraternidade maçônicas foram o princípio gerador da grande revolução, que abateu juntamente o trono e o altar: eis o que é a maçonaria (O Apóstolo, 13 de julho de 1873, ANO VIII, n. 28).

O teor geral da crítica ultramontana e das associações simbólicas promovidas em torno da maçonaria persiste nos anos seguintes. Contudo, vale mencionar que, mediante os acontecimentos que detonaram a Questão Religiosa, a tônica dos seus artigos direciona-se para a situação das províncias de Pernambuco e do Pará, no que toca às irmandades e à suspensão de seus integrantes maçons. Conforme a edição de no. 07, de 16 de fevereiro de 1873: 
Acontecimentos importantes se estão dando nesta província [Pernambuco]. Satanás corre o mundo, e onde acha mais sólida a verdade, aí assenta acampamento e começa sua obra de destruição. Pernambuco outrora admirado por sua constância na fé, por seu amor à Igreja, contando na sua academia defensores sublimes do catolicismo, é hoje vítima da impiedade desenfreada (O Apóstolo, 16 de fevereiro de 1873, ANO VIII, n. 07).

Na sequência, o artigo apoiava a postura do bispo de Pernambuco - D. Vital - que estreava seu episcopado "cuidando em extirpar do rebanho confiado aos seus desvelos, uma seita denominada 'Maçonaria', a qual principalmente nesta época está causando males incalculáveis na família católica”. Assim, os redatores do jornal elogiavam as ações do bispo, clero e corpo capitular da província, por irem "prevenindo seus filhos espirituais contra maquinações tão funestas à salvação das almas", manifestando a adesão do "seu pensar ao do venerável Pastor da diocese Olindense e condenando uma sociedade justamente anatematizada por muitos soberanos Pontífices e ultimamente por Pio IX o Grande (O Apóstolo, 16 de fevereiro de 1873, ANO VIII, n. 07). Combatia, ainda, a "imprensa ímpia" da província paraense, em especial o periódico maçônico O Pelicano ${ }^{12}$, que atacava o clero católico em suas publicações:

Ainda não deixaram de perturbar o espírito público os agentes da maçonaria (...) Há no Pará o Pelicano, que é audaz em defender a maçonaria e pertinaz na missão de injuriar, que gratuitamente tomou a si; não há ponto em que não tenha tocado para atacar a Igreja; a honra de seus ministros, de suas famílias tem sido trazida à discussão. É um herói na maldade (O Apóstolo, 16 de fevereiro de 1873, ANO VIII, n. 07).

Dessa forma, ao posicionar-se acerca da situação nas províncias do Pará e de Pernambuco, O Apóstolo reiterava o discurso maniqueísta, mediante o qual O Pelicano seria "um herói da maldade", assim como no primeiro trecho do artigo a maçonaria era vista como resultado da "ação de Satanás", elemento de destruição da verdade católica e ameaça ao catolicismo. O Apóstolo finalizava o artigo prestando "homenagem de respeito ao clero das duas províncias, Pernambuco e Pará, que está dando ao clero das outras dioceses exemplos tão dignos de imitação (O Apóstolo, 16 de fevereiro de 1873, ANO VIII, n. 07).

A polêmica com a maçonaria desdobrava-se na forte oposição de parte da hierarquia da Igreja contra o placet régio e a liberdade religiosa. O Apóstolo,

12 O Pelicano, periódico paraense fundado em 1872 em defesa da Maçonaria. 
na edição de $n^{\circ} .27$, do dia 7 de julho de 1872, publica uma carta do então Bispo de Diamantina, D. João Antônio dos Santos, aos habitantes da cidade, argumentando sobre a maçonaria:

A maçonaria tem sido condenada por muitos Papas, com excomunhão maior [de] todos seus membros, e [d]os que a coadjuvam ou correm nessa gravíssima pena (...) Procuraram os maçons defender-se contra a excomunhão, dizendo quais Bulas dos Papas, que os condenam, não foram aceitas pelo governo, e por conseguinte não obrigam. Não aceitamos esta objeção da parte dos liberais, que não a aduziriam, se fossem coerentes com seus princípios: pois que propagam a liberdade da consciência, deixem os católicos romanos seguir livremente a sua religião, e não ponham-lhes embaraço na sua prática, e instituições. Se querem que demos a César o que é de César, deixem nos dar a Deus o que é de Deus. Demais, se os Concílios e Bulas dos soberanos Pontífices necessitassem do placet dos governos, a religião católica não se teria propagado por todo o mundo (O Apóstolo, 7 de julho de 1872, n. 27).

$\mathrm{Na}$ interpretação ultramontana, portanto, quando a liberdade da Igreja era barrada pelo placet régio, tratava-se de censura, de impedir que a Igreja avançasse. Ao se oporem ao placet régio, por sua vez, os redatores do Apóstolo confrontavam diretamente com o modelo galicano, mediante o qual a Igreja permaneceu institucionalmente fundida ao Estado e privada, segundo o jornal de "dar a Deus o que é de Deus". Desse modo, no plano discursivo criavam associações simbólicas entre a maçonaria e o regalismo, argumentando que a primeira encontrava apoio junto aos regalistas, ambas as tendências valendose da "pleníssima liberdade de imprensa para mentir, caluniar, blasfemar e desmoralizar”. Apontavam, aqui, a contradição dos próprios regalistas que, embora combatessem "qualquer associação religiosa que não queira em tudo e por tudo submeter-se à direção do governo", privilegiava e isentava a maçonaria de toda sindicância, muito embora esta constituísse "verdadeiramente um Estado no Estado”. (O Apóstolo, 26 de junho de 1870, ANO V, n. 27).

Em continuidade a estes argumentos, $O$ Apóstolo publicava, em 26 de outubro de 1873, edição no. 43, um artigo assinado por Pedro Autran da Matta Albuquerque, sobre dois erros elencados por Pio IX sobre a relação entre poder eclesiástico e poder temporal. Os erros seriam as afirmações: $n^{\circ} 42$, "No conflito das leis civis e eclesiásticas prevalece o direito civil" (Syllabus, 1864), e n 54, "Os reis e os príncipes não só estão isentos da jurisdição da Igreja, como também para resolver as questões de jurisdição lhe são superiores" (Syllabus, 1864). Segundo Autran, haveria uma hierarquia entre os dois poderes, mediante a qual o poder eclesiástico seria naturalmente superior: 
O poder espiritual é de instituição divina imediata; o poder temporal de instituição divina mediata. O primeiro imutável na sua forma; o segundo variável. O primeiro é uno e universal, porque abrange todos os fiéis sem distinção de nacionalidades; o segundo, porém, é múltiplo e limitado. Finalmente, o fim do primeiro é a felicidade eterna do gênero humano; e do segundo a facilidade terrestre. (...) Do exposto se deixa ver que um dos dois poderes sobre-exede [sic] ao outro pela sua instituição, pela sua catolicidade e pelo seu fim superior. Pela mesma natureza, pois, dos dois poderes o temporal não está para com o espiritual numa relação de igualdade, mas de inferioridade. Logo, a subordinação do primeiro ao segundo é natural. (O Apóstolo, n. 43, 1873).

A "catolicidade" - ou universalidade da Igreja -, ao invocar as noções de veritas e ecclesia, reforçava o caráter do catolicismo como única e verdadeira religião e da Igreja católica como instituição superior ao poder temporal. Neste ponto, portanto, a crítica ultramontana esbarrava na presença protestante no Brasil que, na conjuntura assinalada, constituía seu mais direto concorrente na disputa pelo capital simbólico.

Conforme passaremos a analisar, além de estar diretamente relacionada ao tema da liberdade religiosa - simpático a uma elite política que, crescentemente, assumia tal liberdade como mais um ícone da modernidade ocidental e a concebia como condição para os projetos imigrantistas (PEREIRA, 2008, p. 109) -, a ameaça protestante foi relacionada à maçonaria no discurso ultramontano. Por um lado, tal associação repousava no teor das declarações dos próprios protestantes, os quais não negaram auxílios mútuos entre a maçonaria e seus missionários; por outro, foi construída no plano discursivo a partir de uma argumentação de base teológico-filosófica, aplicada à conjuntura observada. De tal forma que, seguindo interpretação de Vieira (1980), a maçonaria e o protestantismo configuraram-se nos elementos centrais do conflito entre Estado e Igreja Católica no período analisado.

\section{O protestantismo e a questão da liberdade religiosa}

Entre os anos de 1872 e 1873, O Apóstolo publicou na seção "Variedades", uma série de artigos ${ }^{13}$, intitulados "Palestras familiares sobre o protestantismo de hoje", que transcrevem trechos do livro do Monsenhor de Ségur, intitulado $A$ s palestras sobre o protestantismo, direcionado aos católicos com o intuito de preservar e defender a Igreja, o que era visto como um direito é

13 O livro de Monsenhor de Ségur, intitulado As palestras sobre o protestantismo, foi publicado pelo Apóstolo em várias edições do ano de 1873. 
um dever do católico. Tais artigos nos permitem perceber a conotação que o pensamento ultramontano emprestava ao protestantismo naquele momento, conforme atesta a edição $\mathrm{n}^{\circ}$. 14 , de 7 de abril de 1872 , na qual o autor diferenciava protestantismo e protestante:

Os protestantes são homens que Deus ama, como ama todos os homens; e o protestantismo é uma revolta que Deus detesta e amaldiçoa na terra, como detesta e amaldiçoa no céu a revolta de seus anjos rebeldes. Devemos amar os protestantes e detestar o protestantismo, como devemos amar o pecador e detestar o pecado (...) O Protestantismo é uma doutrina enganadora: guerra ao erro (O Apóstolo, 7 de abril de 1872, ANO VII, n. 14).

Na edição no. 15, de 14 de abril de 1872, o autor explicava a diferença entre catolicismo e católico, como citado:

O Catolicismo, pelo contrário, é sempre melhor que os católicos, o católico, por mais santo e perfeito que suponham, conserva sempre imperfeições da fraqueza humana e os vestígios do pecado original. A Igreja católica, que é o guia no caminho de Deus, apresenta-lhe a verdade pura de qualquer mistura e absolutamente boa; propõe-lhe a santidade perfeita e acha-se por conseguinte sempre superior ao seu discípulo (O Apóstolo, 14 de abril de 1872, ANO VII, n. 15).

Nesse trecho, o jornal volta a destacar os elementos da veritas e da eclesia para legitimar o catolicismo como religião verdadeira e confirmar a diferenciação entre o sacerdote e o leigo, de modo a preservar o monopólio da Igreja e seus representantes na produção e veiculação do capital religioso (BOURDIEU, 1982). O autor segue fazendo uma diferenciação entre os próprios católicos:

Há católicos e católicos: verdadeiros católicos e católicos de contrabando; católicos sérios, que conhecem e praticam a religião de todo coração, e se dedicam à oração, à penitência, às obras de caridade, à união íntima com Nosso Senhor; e católicos que pelo contrário, só o são de nome, que vivem em indiferença religiosa, que não rezam, que, não tomam os sacramentos, e que são negligentes no serviço de Deus. É necessário não confundir uns com os outros como tipo de católico em geral (O Apóstolo, 14 de abril de 1872, ANO VII, n. 15).

A ênfase do argumento está na suposta perfeição da Instituição e na observância dos sacramentos por parte dos leigos católicos, qualificados como 
"verdadeiros" ou "de contrabando". Neste ponto, o recurso qualificativo demonstra o quanto os representantes do ultramontanismo estavam cientes do fato de que os católicos no Brasil praticavam diferentes catolicismos, que em muitas de suas versões - como era o caso das práticas religiosas representativas do regalismo e do "catolicismo popular" - eram condenados e submetidos às tentativas de homogeneização e enquadramento institucional pelas diretrizes da Santa Sé ${ }^{14}$.

Na continuação de seu argumento, Monsenhor de Ségur estendia o critério de qualificação também aos protestantes:

Do mesmo modo há protestantes e protestantes: protestantes ardentes, e esforçados na guerra contra a Igreja, animados do espírito da seita e de propaganda; e protestantes que pelo contrário só se conservam protestantes porque o são desde que nasceram, que pouco se importam com o que pregam seus ministros, e que não sabem mesmo a qual das mil seitas protestantes pertencem. Não confundamos essas duas classes de protestantes. Os primeiros são sectários, inimigos ativos, cujo zelo cego reveste todos os disfarces para conseguir seu fim desastroso, e que é necessário desmascarar combater. Os outros são simplesmente indiferentes, que não são nem amigos nem inimigos da verdade, e que só resta despertar e esclarecer ( $O$ Apóstolo, 14 de abril de 1872, ANO VII, n. 15).

Essa diferenciação servia para qualificar o grau do erro dos dissidentes, distinguindo entre os "inimigos" e os "indiferentes à verdade", atribuindo-se aos protestantes ativos o crime de "heresia", definida como sendo o "pecado contra a fé (...) a revolta voluntária e obstinada contra o ensino divino da Igreja de Jesus-Cristo", que "transtorna a ordem estabelecida por Deus, e separa o homem da grande família católica que é, na terra como no céu, a família de Deus". Por isso, era apresentada como:

(...) um pecado muito mais grave, um mal muito mais profundo e pernicioso que a libertinagem e todos os vícios que dela se originam. Esses pecados são certamente maus, e afastam muito de Jesus-Cristo, mas não causam na alma uma confusão tão fundamental e perigosa como a heresia. Pode avaliar-se por isto a responsabilidade religiosa, e a enorme culpabilidade desses chamados

14 Esse catolicismo popular resultava das vivências das religiosidades que ganhavam marcas das dinâmicas de hibridismos culturais. Momentos privilegiados tanto das manifestações do catolicismo barroco, quanto dos hibridismos, eram, segundo Martha Abreu, representados pelas "festas organizadas pelas Irmandades em homenagem aos santos padroeiros, ou outros de devoção, eram o momento máximo da vida dessas associações.” (ABREU, 1994, p. 35). 
pastores evangélicos que espalham em torno de si a heresia! (O Apóstolo, 19 de Maio de 1872, ANO VII, n. 20).

Aqui, mais uma vez, na defesa da autoridade hegemônica da Igreja e da condição de seus representantes como detentores do monopólio do capital simbólico, Monsenhor Ségur opunha a ortodoxia católica ao que considerava como "heresia", qualificada a partir da dupla conotação: como "falsa crença" - remetendo ao seu caráter intelectivo - e como prática exteriorizada - a pertinax defensio - capaz de levar o fiel ao "erro". Citando Santo Agostinho, a edição de no 21 do Apóstolo dava sequência ao argumento do Monsenhor de Ségur, que diferenciava o "erro" da "heresia", a partir deste aspecto volitivo:

O erro involuntário é uma desgraça e não um pecado; por conseguinte podemos salvar-nos mesmo em erro; mas heresia sendo revolta contra Deus e sua Igreja, é um pecado, é um crime, e por essa razão não podemos salvar-nos estando em heresia (...) (O Apóstolo, 26 de maio de 1872, ANO VII, n. 21).

Outras questões também aparecem durante esse período, como a condenação das sociedades bíblicas pela Igreja Católica e as atividades proselitistas "que fazem os emissários das sociedades protestantes inglesas nos países católicos” ( $O$ Apóstolo, n. 51, 1872). Neste ponto, a crítica ultramontana apoiada no elemento volitivo - a exteriorização pública das "falsas crenças" era reforçada pelo seu significado político. Em diversos de seus números, os redatores do Apóstolo apontavam a contradição da defesa da liberdade de culto e do proselitismo praticado pelos protestantes com a Constituição do Império, cujo Art. $5^{\circ}$. preservava a condição oficial da religião católica apostólica romana, franqueando às demais religiões apenas a liberdade de culto doméstico ou particular, não sendo concedida ao protestantismo nenhuma vantagem em relação a qualquer outro credo diferente do católico (NOGUEIRA, 2001, p. 80). Desse modo, argumentava:

Dar o nome de Culto legal a propaganda criminosa, e tão criminosa como seria aquela que publicamente conspirasse contra as instituições, que juramos defender, que os protestantes ostensivamente exercem, principalmente nas cidades do Sul do Império, se não é zombar com este nosso crédulo e bom povo, é alguma coisa mais, é trair a missão que se exerce ( $O$ Apóstolo, 2 de janeiro de 1870, ANO V, n. 1). 
Nestes termos, politizava-se o conceito de "heresia", o qual aparecia como um duplo crime - contra a Igreja e Estado -, justificando que a tolerância religiosa não fosse além dos limites estipulados pela Constituição de $1824^{15}$. $\mathrm{Na}$ edição de 27 de fevereiro de 1870, a propósito da "correspondência assinada por um Crente, publicada no Jornal do Comércio, do 21 do corrente”, os editores do Apóstolo indignavam-se:

A tolerância religiosa entre nós não vai, nem pode ir até a propaganda, como parecem entendê-la o governo e os seus prepostos. Em uma nação como o Brasil, onde os cidadãos estão de posse da verdade religiosa, é um crime consentir que se ensine o erro: que se dê à tolerância religiosa a extensão que lhe concedem. E tanto mais criminoso é este proceder, quanto para os católicos se lhes tolhe até a liberdade de resistir com a lei a essas repetidas tentativas de especuladores, que de tudo se utilizam para seus fins criminosos (O Apóstolo, 27 de fevereiro de 1870, ANO V, n. 9).

Nos anos de 1874 e 1875, o jornal deixou de ser semanal, passando a ser publicado em média três vezes por semana, mas sem regularidade quanto aos dias. A edição de domingo manteve-se; contudo, conforme a necessidade, o jornal tinha publicação na terça, na quarta, na quinta ou na sexta-feira, triplicando o número de suas edições. Neste período, a ameaça protestante foi potencializada pelos acontecimentos nas províncias do Pará e Pernambuco, além do fato de que o "ordenamento jurídico imperial foi alargando os limites à liberdade religiosa", opondo a uma "minoria fiel ao Vaticano", uma elite política que, crescentemente, assumia a liberdade religiosa como mais um ícone da modernidade ocidental, apoiando e consolidando a "ideia de que o Estado brasileiro devia ampliar ao máximo as liberdades individuais no que dizia respeito à fé" (PEREIRA, 2008, p. 109) ${ }^{16}$.

15 Neste ponto, vale notar que, se nas primeiras décadas do Império, o número de protestantes radicados no Brasil era insignificante e a "tolerância da população e do clero para com os heterodoxos estrangeiros era espontânea", o cenário mudaria a partir da década de 1850, quando a extinção do tráfico passou a impor a viabilização da imigração de europeus para a formação do mercado de trabalho livre e quando a "quantidade de missionários protestantes que vinham, especialmente, dos Estados Unidos para evangelizar os brasileiros já era significativa." (PEREIRA, 2008, p. 106)

16 As medidas legislativas e administrativas adotadas pelo poder público para adequar-se à nova situação ensejada pela presença, ainda pequena, embora crescente, de protestantes radicados no Brasil, foram bem demonstradas por Boanerges Ribeiro e David Gueiros Vieira (Ribeiro, 1973; Vieira, 1980: 79-123). 
Assim, na edição de ño. 63, de 31 de maio de 1874, O Apóstolo transcrevia um artigo do Diário de Belém a respeito da prisão do Bispo do Pará, D. Antônio Macedo Costa, apontando que a liberdade de culto não pode existir barrando a Igreja de sua submissão a Roma:

Não é o Bispo do Pará quem acaba de ser preso em consequência de uma pronúncia, que não tem assento nas leis do país, como não é o Bispo de Pernambuco, quem está encarcerado por efeito de uma condenação monstruosa: é o princípio religioso que se procura gastar na consciência pública para substituí-lo pelo racionalismo que não é de hoje nem de ontem que lhe oferece duelo para obliterar todos os princípios em que assenta a sociedade moderna, e constituí-la ao alcance das paixões e dos excessos lamentáveis, que testemunhamos ainda não há muito tempo no coração de um povo que caminha na vanguarda da civilização (...) Estabeleça-se, se é preciso, a liberdade de culto ao ponto de permitir-se aos regalistas o direito de ter em S. Cristóvão o seu Papa, aos maçons na sua loja, aos egoístas no seu eu: mas não se negue ao católico o acerto de tê-lo em Roma, de Obedecê-lo, venerá-lo e respeitá-lo enquanto ao menos se mantiver no círculo de ação que ao cidadão traçam as leis do país (O Apóstolo, 31 de maio de 1874, ANO IX, n. 63).

A respeito da liberdade religiosa e do protestantismo, $O$ Apóstolo, na edição de $\mathrm{n}^{\circ} .6$, de 15 de janeiro de 1874, publicava um artigo da revista estadunidense, Catholic World, que versava sobre a obra de Abbade Martin, fazendo uma análise do conceito de liberdade ${ }^{17}$.

A Igreja foi instituída, como crê todo o católico que compreende sua religião, para guardar e defender os direitos de Deus na Terra, contra todo e qualquer inimigo, em todos os tempos e em todos os lugares. Não pode pois ela, nem pode aceitar ou favorecer, por qualquer forma, a liberdade no sentido que dão os protestantes a esta palavra e se esse é o verdadeiro sentido da palavra, liberdade, não se pode com fundamento contestar a pretensão protestante. Mas a liberdade, nós já vimos, no sentido protestante, não é liberdade alguma, ou então é uma liberdade que se identifica, na ordem civil e política com o cesarismo, que é o absolutismo do povo, ou da contingente maioria do momento, numa democracia (O Apóstolo, 13 de janeiro de 1874, ANO IX, n. 6).

Nesse trecho, o autor deixa claro que a missão da Igreja católica é "defender os direitos de Deus na Terra". Por se tratar de uma religião que

17 Esse artigo é traduzido nas edições de $n^{\circ}$ 06, 07, 08, 12 e 18 de 1873. 
se vê como a única verdadeira, a liberdade não poderia ser tolerada, pois tal era associado à promoção do "erro" em matéria doutrinária. Na edição n”. 7, de 18 de janeiro de 1874, o autor continua o artigo, referindo-se ao protestantismo como representando "uma teoria, uma doutrina, uma concepção da religião, e não a própria realidade objetiva", sendo, portanto, "incompatível com a afirmação da liberdade religiosa", uma vez que, não sendo religião:

Tudo quanto ele pode fazer é reivindicar para o Estado o direito ou a faculdade de adotar e ordenar a concepção da religião que ele porventura abraçar; é atribuir à comunidade a faculdade de formar e de impor as suas próprias concepções, convicções ou opiniões; e o indivíduo a faculdade de forjar uma religião que lhe convenha, ou de prescindir inteiramente da religião, se assim lhe aprouver. Em nenhum destes casos existe liberdade religiosa alguma; e em todos eles a religião fica sujeita à autoridade puramente humana, ou do Estado, ou da comunidade ou do indivíduo; tão humana uma como as outras (O Apóstolo, 18 de janeiro de 1874, ANO IX, n. 7).

Além de apontar a suposta incompatibilidade entre protestantismo e liberdade religiosa, o artigo avançava sobre o que deveria ser entendido como a própria "liberdade de consciência", a qual, argumentava: "não consiste na sua emancipação de toda e qualquer lei, pois isso seria sua destruição; consiste, sim, em não estar sujeita a nenhuma outra lei senão à lei de Deus, promulgada por autoridade divina e manifestada ao entendimento pelo próprio Deus, ou por um tribunal instituído pelo Espírito Santo, e por ele iluminado e assistido". Sendo assim, concluía: "Sob o regime do protestantismo não há nem pode haver liberdade de consciência, pois sob ele ou a consciência fica destruída por não estar sujeita a lei alguma, ou fica escravizada por estar sujeita à lei diversa da lei de Deus outras (O Apóstolo, 18 de janeiro de 1874, ANO IX, n. 7).

Dessa forma, nota-se que na visão dos redatores do jornal, "liberdade da Igreja" - associada à defesa da autonomia institucional da Igreja em ao Estado - não se confundia com "liberdade religiosa" - a qual significava franquear o culto público às outras denominações cristãs, concorrentes do catolicismo. Na conjuntura observada, a postura ideológica defendida pelo jornal O Apóstolo afinava-se com a primeira, mas repudiava a liberdade no segundo sentido, encampando o projeto de uma Igreja Católica "visceralmente ligada à Sé Romana" e submissa à «função e as prerrogativas do Sumo Pontífice», cuja infalibilidade era descrita como "o pesadelo do protestante e do racionalista, do liberalista e do regalista, do judeu e do cismático, do galicano e do 
católico liberal e até - quem diria! - do ímpio e do ateu!!! Todos têm medo da infalibilidade do Papa, como o desertor tem medo da farda" (O Apóstolo, 5 de abril de 1870, ANO V, n. 14).

\section{Considerações finais}

O presente artigo buscou identificar a dinâmica discursiva ultramontana registrada naquele que foi um dos seus principais porta-vozes, na segunda metade do século XIX: o jornal O Apóstolo. Nas suas páginas, a Questão Religiosa foi interpretada e encaminhada a partir da polarização entre os defensores do catolicismo e adeptos das diretrizes da Santa Sé - leigos e clérigos -, e aqueles que foram genericamente englobados na condição de heréticos e anticlericais, representados centralmente pela maçonaria e o protestantismo.

Se no calor dos acontecimentos transcorridos entre 1872 e 1875, estes concorrentes que disputavam legitimidade política e visibilidade social no interior de um mesmo campo religioso cristão foram anatemizados pelo ultramontanismo, nos seus desdobramentos o encaminhamento político daquela que se configurava na principal questão do momento - a redefinição do papel da religião na sociedade secular e crescentemente adepta dos ícones associados à modernidade em voga no mundo ocidental - selaria a separação oficial entre Igreja e Estado, conferindo legitimidade ao projeto laico, cujos princípios foram consolidados na Constituição de $1891^{18}$.

Tais desdobramentos levariam os próprios representantes da Igreja a reconsiderarem os temas pungentes na conjuntura analisada, senão no seu sentido doutrinal (intelectivo), ao menos em termos práticos, no que tange, por exemplo, ao tratamento dispensado à questão exteriorização pública de outros cultos religiosos (pertinax defensio), ou que iam assim sendo enquadrados (GUIMBELLI, 2016). Isto porque, mediante o avanço do protestantismo acusado de "perseguidor; porque ligado por toda a parte com o racionalismo e o maçonismo, que se há apoderado dos governos católicos, persegue a Igreja por toda a parte" (O Apóstolo, 5 de abril de 1874, ANO IX, n. 40) - a pró-

18 No texto revisado e modificado pelo jurista Rui Barbosa (1849-1923) - preconizador da vertente secularizante que vingou no período republicano, ao associar a liberdade religiosa aos "traços do pensamento liberal que afirmavam o princípio da autonomia do indivíduo" e da "independência da razão" (CIARALLO, 2011, p. 95) -, estipulava-se que "Todos os indivíduos e confissões religiosas" poderiam, desde então, "exercer pública e livremente o seu culto, associando-se para esse fim e adquirindo bens, observadas as disposições do direito comum".(BALEEIRO, 2001, p. 96) 
pria Igreja passou a tolerar e a conviver com práticas religiosas que não se enquadravam nas diretrizes tridentinas, como é o caso das festas de santos católicos e os "batuques, cantorias e danças" dos "pretos", o que gerou uma alternância entre ações repressoras e ações de tolerância "para evitar mal pior": uma pluralidade religiosa representada pela expansão das religiões protestantes (ABREU, 1994). A propósito do jornal aqui analisado, Martha Abreu comenta que, a partir da década de 1880:

para combater os seus maiores inimigos, o liberalismo e o protestantismo, O Apóstolo foi veículo de um tipo de tolerância que complementa todas as outras. Afirmava a existência de uma nacionalidade católica, incorporando todos os brasileiros, inclusive os escravos (em geral, não "tão bons católicos assim”) numa só família, com uma mesma religião, costumes e língua (ABREU, 1994, p. 198-199).

Portanto, a eminência do republicanismo e a presença protestante, assim como as posturas anticlericais - pautadas num modelo de secularização cada vez mais apoiada no princípio laico - emprestariam outra tônica ao discurso registrado nas páginas do Apóstolo. A conjuntura histórica que antecedeu a proclamação da República proporcionou que temas antes indiscutíveis na sociedade brasileira pudessem não só vir à tona, mas encontraram campo fértil para um conjunto de reformas que caracterizaram uma "modernização conservadora incompleta", amparada numa nova "estrutura de oportunidades políticas", na "comunidade de experiência" e num "repertório" (de temas, conceitos, teorias...) (ALONSO, 2000, p. 42).

Neste cenário, se por um lado os representantes do catolicismo continuaram reivindicando seu status como legítimos detentores do monopólio do capital simbólico religioso - ou ao menos de privilégios neste sentido, conforme aqueles contemplados pela Constituição de 1834 -, por outro, precisaram apropriar-se de temas, termos e conceitos forjados pelas próprias vertentes liberais da secularização em curso, implicando o próprio envolvimento das instituições religiosas com questões cada vez mais mundanas e menos espirituais (RANQUETAT, 2012, p. 17). Afinal, ao agirem publicamente, os sujeitos religiosos "vêem obrigados a aprender, em cada situação específica, a gramática e a semântica relacionada ao modo de organização de cada cultura pública particular", o que fazem "geralmente no exercício da própria prática, se expondo e desafiando o senso comum (MONTERO, 2012, p. 176). 
De tal forma que, no Brasil da segunda metade do século XIX e primeiras décadas do XX, as supostas condições da modernidade continuaram apresentando uma inegável ligação com o religioso.

\section{Referências}

ABREU, M.. Festas religiosas no Rio de Janeiro: perspectivas de controle e tolerância no século XIX. Revista Estudos Históricos, 7:14, p. 205-230, 1994.

ALONSO, A.. Crítica e contestação: o movimento reformista da geração 1870. Revista Brasileira de Ciências Sociais, v. 15, n. 44, p. 35-55, 2000.

ASAD, T.. Formations of the Secular: christianity, islam, modernity. California: Stanford, 2003.

BOURDIEU, P.. A economia das trocas simbólicas. São Paulo: Perspectiva, 1982.

BURNS, J.H; IZBICKI, T.M. Conciliarism and Papalism. Cambridge: Cambridge University Press, 1997.

CAVALLERO, C.. La temporalidad del lenguaje de la herejía. El caso de la construcción de la herejía judaizante en el ocaso de la Edad Media. Medievalismo, Vol. 22, pp.11-35, 2012..

CARVAlho, J.. A construção da ordem. A elite política imperial. Brasília: Editora Campus, 1981.

CASANOVA, J.. Rethinking secularization: A global comparative perspective. Religion, globalization, and culture. Brill, p. 101-120, 2007.

CIARALLO, G.. O tema da liberdade religiosa na política brasileira do século XIX: uma via para a compreensão da secularização da esfera política. Revista de Sociologia e Política, v. 19, n. 38, p. 85-99, 2011.

DI STEFANO, R.. Disidencia religiosa y secularización en el siglo XIX iberoamericano: cuestiones conceptuales y metodológicas. Projeto História: Revista do Programa de Estudos Pós-Graduados de História, v. 37, n. 2, p. 157-178, 2008.

DI STEFANO, Roberto. Ovejas Negras - Historia de los anticlericales argentinos. Buenos Aires: Sudamericana, 2010.

GIUMBELLI, E. A.. Regulação do religioso: discussões conceituais e panorama da situação em quatro países latino-americanos. Ciencias sociales y religión. Porto Alegre, RS. Vol. 18, n. 25 (dez. 2016), p. 14-37, 2016.

GONÇALVES, T. W.. O periodismo maçônico oitocentista da Corte imperial brasileira (1871-1874). 2012. 2012, 181 f. Dissertação (Mestrado em História Social). Universidade Federal Fluminense. Niterói. 
LUSTOSA, O. F.. Os bispos do Brasil e a imprensa. São Paulo: Loyola, 1983.

MONTERO, P.. Controvérsias religiosas e esfera pública: repensando as religiões como discurso. Religião \& Sociedade, n. 1, 32.1: p.167-183, 2012.

MONTERO, P.. Religião, pluralismo e esfera pública no Brasil. Novos Estudos-CEBRAP, n. 74 , p. $47-65,2006$.

MONTERO, P.. Secularização e espaço público: a reinvenção do pluralismo religioso no Brasil. Etnográfica. Revista do Centro em Rede de Investigação em Antropologia, v. 13, n. 1), p. 7-16, 2009.

O APÓSTOLO: Periódico religioso, moral e doutrinário, consagrado aos interesses da religião e da sociedade. Rio de Janeiro: 1866 a 1892. Disponível : < $\underline{\text { http://memoria.bn.br/DocReader/ }}$ docreader.aspx?bib=343951\&pesq=> . Acesso em: de setembro de 2016 a novembro de 2018 .

ORO, A. P.. A laicidade no Brasil e no Oriente: algumas considerações. Civitas: revista de ciências sociais. Porto Alegre, RS. Vol. 11, n. 2 (maio/ago. 2011), p. 221-237, 2011.

PEREIRA, R. N. M.. A primeira das liberdades: O debate político sobre a liberdade religiosa no Brasil Imperial. Desigualdade \& Diversidade, (PUCRJ), v. 1, p. 6, p. 98-121, 2007.

PEREIRA, R. N. M., A salvação do Brasil: as missões protestantes e o debate político-religioso do século XIX. 2008. 436 f.. Tese de Doutorado (Doutorado em História Política). UERJ, Rio de Janeiro.

QUANTA CURA, 1864. Disponível em: < $\underline{\mathrm{http}}$ ///w2.vatican.va/content/pius-ix/it/documents/ encyclica-quanta-cura-8-decembris-1864.html>. Acesso em: 06 de out. de 2017.

RANQUETAT JÚNIOR, C. A.. Laicidade à Brasileira: estudo sobre a controvérsia em torno da presença de símbolos religiosos em espaços públicos. Jundiaí: Paco Editorial, 2016.

SANTIROCCHI, I. D.. A coragem de ser só: Cândido Mendes de Almeida, o arauto do ultramontanismo no Brasil. Almanack, v. 1, n. 7, p. 59-80, 2014.

SANTIROCCHI, I. D.. O matrimônio no Império do Brasil: uma questão de Estado. Revista Brasileira de História das Religiões, 4.12. p. 81-122, 2012.

SANTIROCCHI, I. D.. O paradigma tridentino e a Igreja Católica no Brasil oitocentista: modernidade e secularização. Reflexão, v.42, n.2, p.169-181, 2017.

SANTIROCCHI, I. D.. Uma Questão de Consciência: Os Ultramontanos no Brasil e o Regalismo do Segundo Império (1840-1889). Belo Horizonte: Fino Traço/São Luis: EDFMA, 2015. 
SANTIROCCHI, I. D.. Uma questão de revisão de conceitos: Romanização-Ultramontanismo -Reforma. Temporalidades, 2.2: p. 24-33, 2010b.

SILVA, A. R. C.. As experiências da Modernidade e da Secularização no discurso ultramontano da segunda metade do século XIX: uma discussão a partir da história dos conceitos. In: VI Congresso da ANPTECRE- "Religião, Migração e Mobilidade Humana", 2017, Goiânia. Anais do VI Congresso da ANPTECRE. Goiânia: Pontifícia Universidade Católica de Goiás, v. 1. p. 101-108, 2017.

SILVA, A. R. C.; CARVALHO, Thaís da Rocha. Ultramontanismo e protestantismo no período regencial: uma análise da crítica panfletária dos padres Perereca e Tilbury à missão metodista no Brasil. Almanack, 15: p. 106-142, 2017.

SYLLABUS, 1864. Disponível em: < http://w2.vatican.va/content/pius-ix/it/documents/ encyclica-quanta-cura-8-decembris-1864.html>. Acesso em: 06 de out. de 2017.

VIEIRA, D. G.. O protestantismo, a maçonaria e a questão religiosa no Brasil. Basília: Editora UnB, 1980.

VIEIRA, D. R.. O processo de reforma e de reorganização da Igreja no Brasil (1844-1926). Aparecida: São Paulo, 2007.

Submetido em: 5-3-2019

Aceito em: 25-8-2019 